\title{
Pandemi COVID-19 dan Gebu CSR pada Perusahaan Adaro Energy
}

\author{
${ }^{1}$ Ainun Arizah, ${ }^{2}$ Khadijah Darwin, ${ }^{3}$ Ramly, ${ }^{4}$ Ahmad Abbas \\ 1,2,3 Universitas Muhammadiyah Makassar \\ ${ }^{4}$ Sekolah Tinggi Agama Islam Negeri Majene \\ Email Korespondensi: ainunarizah@unismuh.ac.id
}

\begin{abstract}
Abstrak. Penelitian ini bertujuan untuk mengungkapkan keputusan PT. Adaro Energy dalam berdonasi selama pandemi COVID-19 dan memahami donasi tesebut dalam meningkatkan citra bisnis. Penelitian ini merupakan penelitian kualitatif dengan pendekatan semiotika. Adapun objek penelitiannya adalah teks naratif atas pengungkapan CSR yang didapat dari website dan media sosial perusahaan. Hasil penelitian ini menunjukkan bahwa Adaro secara aktif bersinergi dengan berbagai pihak selama Pandemi COVID-19 dengan menyalurkan sejumlah donasi. Hal tersebut berhasil meningkatkan citra baik perusahaan sehingga Adaro Energy mampu memperoleh legitimasi dalam bentuk penghargaan dari Badan Nasional Penanggulangan Bencana.
\end{abstract}

\section{Kata kunci: COVID-19, CSR, Legitimasi}

Abstract. This research aims at disclosing the decision made by PT. Adaro Energy in conducting the donation during the pandemic of COVID-19 and understand the donation in boosting the business image. The type of this research is qualitative employing the semiotics approach. The object of this research is the narrative text in terms of CSR obtained from website and social media of Adaro Energy. The result of this research discloses that Adaro Energy is active to synergy with the various stakeholders along the pandemic of COVID-19 through the distribution of the number of donations. It is successful to boost good image of firm so that Adaro Energy can obtain the legitimacy in the form of certificate appreciated by the National Agency for Disaster Management.

Keywords: CSR, COVID-19. Legitimacy

\section{PENDAHULUAN}

Pandemi COVID-19 yang awalnya terjadi di Wuhan, China dan kemudian pada Maret 2020 Indonesia turut merasakannya di mana keselamatan penduduk mulai terancam dan ekonomi global mengalami resesi yang signifikan. Pandemi ini tidak lagi dapat diselesaikan sendiri oleh pemerintah, tetapi mulai mendorong gelombang sosial besar yang turut membantu pemerintah. Salah satu elemen yang ikut membantu pemerintah adalah perusahaan dengan memberikan bantuan berupa donasi. Bantuan yang diberikan perusahaan dinilai sebagai sifat altruistik perusahaan. Dimana, perusahaan tidak dapat secara langsung menerima manfaat dari donasi yang telah ia keluarkan. Perusahaan kemudian menilainya sebagai wujud tanggung jawab sosial perusahaan (CSR). Lebih lanjut, menurut Lantos 2002, wujud kepedulian perusahaan dalam perspektif altruistik yaitu tanggung jawab untuk memenuhi pelaksanaan kebaikan (philantropy) dengan tujuan membantu meningkatkan kebaikan tanpa menghitung usaha ini akan membawa keuntungan atau tidak kepada perusahaan. Terkait dengan pandemi COVID-19, Abbas (2020) menyatakan bahwa keterlibatan perusahaan go public selama pandemi dilakukan dalam bentuk donasi uang, peralatan dan perlengkapan medis serta akses internet gratis. Keterlibatan mereka diakui sebagai wujud dari CSR.

PT. Adaro Energy, Tbk merupakan salah satu perusahaan pertambangan go public yang terdaftar di Bursa Efek Indonesia. Berdasarkan Undang-Undang Perseroan Terbatas Nomor 40 Tahun 2007, disebutkan bahwa Perseroan Terbatas yang menjalankan usaha di bidang dan/atau bersangkutan dengan sumber daya alam wajib menjalankan tanggung jawab sosial dan lingkungan. Salah satu pilihan 
program CSR yaitu corporate philantrophy, berupa inisiatif perusahaan dengan memberikan kontribusi langsung kepada suatu aktivitas amal berupa donasi atau sumbangan tunai (Kotler dan Lee, 2005). PT. Adaro Energy, Tbk pada tanggal 23 Maret 2020 menyerahkan bantuan senilai total Rp. 20 Miliar melalui program "Adaro Berjuang untuk Indonesia" kepada Badan Nasional Penanggulangan Bencana (BNPB) selaku Koordinator Gugus Tugas Percepatan Penanganan COVID-19. Bantuan berupa donasi untuk penanganan COVID - 19 ini dapat dinilai sebagai wujud tanggung jawab sosial (CSR) PT. Adaro Energy, Tbk.

CSR merupakan salah satu bentuk sikap etis yang dilakukan perusahaan (Heimann, 2008 dalam Mardikanto, 2014). Sikap etis PT. Adaro Energy, Tbk dengan memberikan sejumlah donasi untuk membantu pemerintah menangani COVID - 19 secara tidak langsung meningkatkan citra perusahaan. Menurut Caroll, 2010, salah satu alasan perusahaan tertarik untuk melaksanakan CSR terkait dengan citra/ image / reputasi perusahaan. Kemudian pada akhirnya CSR hanya dijadikan sarana perusahaan untuk tampil lebih manusiawi, murah hati dan bertanggung jawab secara sosial (Yusuf, 2017). Penelitian ini tertarik menganalisis semiotika PT. Adaro Energy, Tbk yang giat berdonasi selama pandemi COVID - 19 di Indonesia.

Sebagian besar studi yang menganalisis pengungkapan informasi tanggung jawab sosial perusahaan berfokus pada laporan tahunan (annual report), dimana annual report dianggap sebagai alat yang paling penting yang digunakan perusahaan untuk berkomunikasi dengan stakeholders perusahaan (Branco dan Rodrigues, 2006 dalam Chariri dan Nugroho, 2009). Penelitian yang dilakukan oleh Priyanti, Kamayanti, dan Atmadja, 2010 melakukan analisis semiotik annual report PT. AKR yang berupa teks naratif baik yang berbentuk kalimat maupun gambar, kalimat persuasif yang dapat mempengaruhi pendapat audien dalam menilai kinerja tanggung jawab sosial perusahaan. penelitian lainnya dilakukan oleh Chariri dan Nugroho, 2009 yang menganlisis Semiotik atas Sustainability Reporting PT. Aneka Tambang Tbk.

Berbeda dengan penelitian sebelumnya yang memfokuskan diri menganalisis semiotika dari annual report perusahaan. Penelitian ini mengkhususkan diri menganalisis semiotika dari kegiatan CSR PT. Adaro Energy, Tbk saat pandemi COVID - 19 berlangsung di Indonesia yang dapat dilihat dari website dan media sosial perusahaan. Informasi CSR tersebut dapat melalui gambar dan teks naratif. Teks naratif (narrative text) merupakan bagian yang memainkan peranan penting bagi perusahaan dalam membentuk image perusahaan. Di mana dengan hal tersebut, perusahaan secara aktif berusaha membentuk image positif dan menghindari image negatif (Gardner dan Martinko 1988).

Pilihan PT. Adaro Energy, Tbk untuk mendonasikan sejumlah dana kepada pemerintah dalam menangani pandemi COVID - 19 adalah wujud tanggung jawab sosial perusahaan (CSR). Kondisi pemerintah yang mebutuhkan bantuan direspon cepat oleh Adaro dengan menyalurkan sejumlah donasi. Pilihan Adaro berdonasi tersebut dapat dinilai sebagai wujud pembentukan image positif perusahaan. Perusahaan yang menunjukkan kepedulian dimasa sulit seperti saat pandemi COVID - 19 dinilai akan mendapat legitimasi dari pemerintah dan masyarakat. Hingga pada akhirnya, perusahaan dinilai punya sikap etis dan lebih bertanggung jawab sosial. Oleh karena itu, penelitian ini bertujuan untuk memahami dan menganalisis keputusan donasi PT. Adaro Energy Tbk yang ditampilkan dalam gambar dan teks naratif di website dan media sosial perusahaan serta berbagai berita online yang beredar di internet.

\section{METODE PENELITIAN}

Penelitian ini menggunakan metode kualitatif berupa analisis semiotik naratif atas pengungkapan CSR PT. Adaro Energy, Tbk yang diambil dari website dan media sosial perusahaan. Data kualitatif adalah data dalam bentuk kata-kata seperti wawancara, transkrip kelompok, jawaban pertanyaan terbuka, transkripsi rekaman video, laporan pengalaman dari internet, artikel, berita dan semacamnya (Sekaran dan Bougie, 2019). 
Pada penelitian ini, dihasilkan data deskriptif berupa kata-kata tertulis yang bersumber dari teks naratif atas tindakan CSR PT. Adaro Energy, Tbk saat pandemi COVID-19 di Indonesia.

Tujuan dari penelitian ini adalah untuk menjawab, memahami dan menganalisis keputusan PT. Adaro Energy, Tbk berdonasi selama pandemi COVID- 19 di Indonesia, serta memahami bagaimana donasi tersebut membentuk citra perusahaan. Oleh karena itu, pendekatan kualitatif merupakan pendekatan yang tepat digunakan dalam penelitian ini. Selain itu, penelitian ini menggunakan pendekatan paradigma interpretif, yang memungkinkan peneliti untuk menganalisis dokumen dengan analisis semiotik melalui informasi teks naratif.

Lofland dalam Moleong 2004, sumber data utama dalam penelitian kualitatif adalah kata-kata, dan tindakan, selebihnya adalah data tambahan dokumen dan lain-lain. Metode pengumpulan data yang digunakan yaitu metode dokumentasi dengan mencatat data dari laporan, catatan dan arsip dari beberapa sumber seperti internet, jurnal, penelitian terdahulu dan sumber lain yang relevan. Pada penelitian ini data diperoleh dengan cara mengamati dan menganalisa kegiatasosial perusahaan selama Pandemi COVID - 19 dengan menyalurkan sejumlah donasi lalu mengungkapkan nya di website resmi perusahaan dan media sosial. Kegiatan sosial ini merupakan wujud Tanggung Jawab Sosial Perusahaan (CSR).

Data yang dijadikan objek analisis dalam kajian semiotik adalah teks. Teks dapat digolongkan menjadi dua subgolongan, yakni (a) teks yang mewakili pengalaman, yang dapat dianalisis dengan teknik elisitasi sistematis (mengidentifikasi unsur-unsur teks yang merupakan bagian dari suatu kebudayaan dan mengkaji hubungan di antara unsur-unsur itu) atau analisis teks dengan bertolak dari analisis kata atau teks sebagai sistem tanda, dan (b) teks sebagai objek analisis dengan melakukan analisis percakapan, narasi, parole, atau struktur gramatikal (Ryan dan Bernard, 2000 dalam Haryatmoko, 2008).

Penelitian ini termasuk ke dalam sub golongan (a). Analisis data didasarkan pada pendekatan deskriptif analitik sesuai dengan makna simbol, kata dan kalimat yang ditemui dalam teks atas pengungkapan CSR PT. Adaro Energy, Tbk saat pandemi COVID - 19 di Indonesia.

Analisis data yang dilakukan dalam peneltian ini merupakan analisis semiotik atas teks naratif terkait kegiatan CSR PT. Adaro Energy, Tbk saat pandemi COVID -19 di Indonesia. Analisis semiotik naratif adalah suatu analisis yang menggunakan struktur kalimat sebagai dasar untuk menjelaskan suatu teks naratif.

Menurut Haryatmoko, semiotik merupakan ilmu yang mengkaji tanda dalam kehidupan manusia. Artinya, semua yang hadir dalam kehidupan kita dilihat sebagai tanda, yakni sesuatu yang harus kita beri makna. Adapun langkah analisis yang dilakukan sebagai berikut: (1) Mengidentifikasi kalimat dalam pengungkapan CSR PT. Adaro Energy, Tbk saat pandemi Covid - 19 di Indonesia. (2) Menginterpretasi kalimat dalam teks naratif dengan ketentuan (a) Kalimat diidentifikasi dari struktur sintaktiknya, (b) Kalimat dianalisis dari interpretasi semantiknya, (c) Kalimat dianalisis berdasarkan pada audiens yang dituju, (d) Interpretasi atas teks dilakukan berdasarkan analisis semiotik makna kata/kalimat dengan menggunakan teori yang relevan, dan (e) Deskripsi dan analisis data selanjutnya dituangkan dalam cerita kontekstual dalam hasil penelitian.

\section{HASIL DAN PEMBAHASAN Analisis Semiotika atas Pengungkapan PT. Adaro energy}

PT. Adaro Energy, Tbk merupakan salah satu perusahaan tambang yang kegiatan bisnis nya terkait eksplorasi Sumber Daya Alam. Pasal 74 ayat (1) Undang-Undang Nomor 40 Tahun 2007 tentang Perseroan Terbatas ("UU PT") mengatur bahwa "Perseroan yang menjalankan kegiatan usahanya di bidang dan/atau berkaitan dengan sumber daya alam wajib melaksanakan Tanggung Jawab Sosial dan Lingkungan". Pandemi Covid 19 di Indonesia berlangsung sejak bulan Maret 2020 hingga sekarang. Dalam perjalanannya, PT. Adaro Energy, Tbk secara berkesinambungan mengambil peran sebagai sebuah perusahaan 
dengan menunjukkan tanggung jawab sosial perusahaan nya melalui sejumlah donasi yang mereka salurkan kepada lembaga pemerintah serta kelompok masyarakat. Data dikumpulkan dari website resmi perusahaan, serta media sosial resmi perusahaan yaitu instagram @adaroenergy

\section{a. Website resmi PT. Adaro Energy, Tbk}

Sejak awal Pandemi Covid 19 melanda Indonesia pada bulan Maret 2020, PT. Adaro Energy, Tbk aktif menyalurkan donasi. Kegiatan ini kemudian mereka ungkapkan dengan menerbitkan press release di website resmi perusahaan. Pertama, tanggal 24 Maret 2020 Adaro menyerahkan bantuan senilai $\mathrm{Rp}$ 20 miliar kepada BNPB untuk penangangan Covid 19.

Press release tersebut mengungkap peran aktif Adaro lewat program "Adaro Berjuang Untuk Indonesia" kemudian dilanjutkan dengan judul "Adaro Serahkan Bantuan Rp 20 Miliar kepada BNPB untuk Penanganan COVID-19" lalu dilanjutkan dengan isi. Kedua, tanggal 29 Mei 2020, PT. Adaro kembali menerbitkan press release dengan judul "Adaro dan UI Siap Salurkan 100 Unit Ventilator COVENT-20 ke Rumah Sakit di Indonesia".

\section{b. Instagram Resmi PT. Adaro Energy, Tbk}

Media sosial perusahaan merupakan media penyampaian informasi perusahaan, baik yang terkait dengan kegiatan perusahaan, pencapaian perusahaan, dukungan perusahaan atas isu terkini, hingga media pengungkapan kegiatan sosial perusahaan. Hasil pengamatan pada media sosial Adaro (instagram), ditemukan bahwa mereka secara rutin mem posting sejumlah kegiatan sosial mereka selama Pandemi covid 19.

\section{Maret 2020}

Adaro memposting 3 buah gambar terkait donasi yang mereka keluarkan kepada Badan Nasional Penanggulangan Bencana (BPBD). Gambar 1, foto Presiden Direktur PT. Adaro Energy, Tbk - Garibaldi Thohir dengan Doni Monardo selaku ketua gugus tugas penanganan Covid 19 memegang papan donasi yang Adaro berikan sejumlah Rp. 20 miliar dengan tulisan "Adaro berjuang untuk Indonesia". Kemudian gambar ke 2, menyajikan foto Garibaldi Thohir sedang menyampaikan paparannya di podium dan didampingi Doni Monardo, gambar ini menyajikan kutipan perkataan Garibaldi Thohir "inilah waktunya kita bersama-sama solid bersatu untuk membantu". Lalu gambar ke-3, disajikan gambar Garibaldi Thohir secara simbolis memberikan 'kunci' kepada Doni Monardo. Ketiga gambar ini lalu di posting dengan memberikan caption sebagai berikut.

"Adaro berjuang untuk Indonesia,

Jakarta - Presiden Direktur PT. Adaro

Energy Tbk - Garibaldi Thohir, Perwakilan pemegang saham PT Adaro Energy Tbk. Michael William P. Soeryadjaya, Aminudin Nurdin dan Aditya Irawan menyerahkan bantuan senilai total Rp 20 miliar kepada Badan Nasional penanggulangan bencana (BNPB) yang diwakili oleh ketua gugus tugas penanganan covid 19 - Doni monardo melalui program "Adaro berjuang untuk Indonesia" di Graha BNPB, Jakarta Timur (Senin 23 Maret 2020). BNPB selaku koordinator gugus tugas percepatan penanggulangan coronavirus disease (Covid 19) akan memaksimalkan bantuan tersebut untuk membantu pahlawan tenaga medis dan anggota TNI yang menjadi garda terdepan dalam penanganan Covid 19 serta bantuan penyediaan mobil khusus yang akan membantu mobilisasi pasien atau masyarakat yang terpapar Covid 19. Diharapkan langkah ini menginspirasi perusahaan lain untuk menjadi pahlawan kemanusiaan dan memperkuat sinergi semua pihak demi mempercepat penanggulangan Covid $19 "$.

\section{Maret 2020}

Masih terkait dengan donasi yang diberikan kepada BNPB sejumlah Rp. 20 miliar, Adaro mem posting sebuah video yang berisi rekaman kegiatan Adaro saat berkunjung ke kantor BNPB saat menyalurkan donasi. Video itu berisi penjelasan Doni 
Monardo (Ketua BNPB) terkait dana Rp. 20 miliar yang diterima BNPB dengan ketentuan Rp. 5 miliar disalurkan untuk pengadaan 25 unit ambulans, dan Rp. 15 miliar disalurkan untuk kepentingan tenaga medis. Video ini dilengkapi dengan caption sebagai berikut.

PT Adaro Energy, Tbk menyalurkan bantuan sebesar Rp. 20 miliar kepada Badan Nasional Penanggulangan Bencana (BNPB) untuk melawan Pandemi Covid 19.

"Adaro berjuang untuk Indonesia dan siap menggunakan sumber daya yang kami miliki untuk bersinergi dengan pemerintah dalam penanganan virus corona (Covid 19) di Indonesia. Dalam kondisi seperti ini, kami harus bersama sama, bersinergi dengan semua pihak, sehingga dapat mengatasi dan mempercepat penanggulangan Covid 19. Semoga kontribusi kami ini dapat memberikan manfaat nyata bagi masyarakat dan bangsa Indonesia." kata Presiden Direktur Adaro, Garibaldi Thihit, Senin (23/3)".

\section{Maret 2020}

Masih terkait dengan video yang di posting tanggal 27 Maret 2020, selanjutnya pada tanggal 28 Maret 2020, Adaro kembali mem posting sebuah video dengan narasi video berisi penjelasan bahwa Adaro merupakan perusahaan swasta pertama yang bekerja sama dengan BNPB untuk menyalurkan bantuan sejumlah Rp. 20 miliar yang didonasikan untuk kesehatan. Lebih lanjut, caption atas postingan ini sebagai berikut.

"Pandemi virus corona atau Covid 19 yang menyebar dunia termasuk Indonesia harus dilawan bersama. Berbagai pihak harus bersinergi, mulai dari pemerintah, masyarakat, perusahaan, dan pihak-pihak lainnya agar kita bisa melalui pandemi ini.@ @adaroenergy juga turut berjuang melawan COVID 10 lewat kerja sama dengan@bnpb_indonesia. Adaro menyumbangkan Rp. 20 miliar untuk bantu penanganan corona di Indonesia. Rp. 15 miliar akan dialokasikan untuk pejuang garda depan seperti dokter dan perawat. Sementara itu, Rp. 5 miliar digunakan untuk mobil yang membantu mobilitas penanganan Covid 19." Penyerahan bantuan secara simbolis dilakukan oleh Garibaldi Thohir, Presiden Direktur Adaro kepada Letjen TNI Doni Monardo, Kepala Gugus Tugas Penanganan Virus Corona, yang mewakili BNPB".

\section{Juli 2020}

Adaro kembali mem posting sebuah video terkait peran aktifnya menyalurkan bantuan selama Pandemi Covid 19 melalui program "Adaro berjuang untuk Indonesia". Video ini menampilkan gambar aktivitas sosial Adaro yang dimulai pada tanggal 23 Maret, 18 Mei, 28 Mei, dan 14 Juni. Adapun caption atas video tersebut sebagai berikut.

"Adaro menyadari, seluruh elemen bangsa harus bekerja sama untuk menghadapi pandemi Covid-19. Karena itu Adaro ikut berperan serta membantu pemerintah menangani pandemi, melalui Program Adaro Berjuang Untuk Indonesia"

Berbagai bantuan disalurkan bukan hanya di wilayah operasional Adaro saja, namun untuk seluruh masyarakat Indonesia.

Langkah kami dimulai dengan bantuan senilai total Rp 20 miliar kepada Badan Nasional Penanggulangan Bencana (BNPB) untuk penanganan secara nasional. Termasuk bersama-sama dengan berbagai pihak dalam memberikan 30.000 paket bantuan untuk warga yang terdampak secara ekonomi di 13 kota atau kabupaten di Jabodetabek

Selanjutnya, Adaro juga menyerahkan bantuan senilai Rp 2,5 miliar kepada Universitas Indonesia untuk pembuatan dan pendistribusian 100 ventilator COVENT-20 ke berbagai rumah sakit di Indonesia.

Selain itu, Adaro juga menyerahkan 500.000 masker nonmedis juga untuk masyarakat di berbagai kabupaten di Kalimantan Selatan dan Kalimantan Tengah. 
Harapan kami, langkah ini dapat membantu pemerintah dalam menanggulangi Covid-19.

\section{Oktober 2020}

Adaro mem posting sebuah foto 'prestasi' Adaro yang berhasil menerima penghargaan dari BNPB pada tanggal 15 Oktober 2020. Gambar ini dilengkapi caption yang berisi

"Badan Nasional Penanggulangan Bencana (BNPB) memberikan anugerah kepada Adaro atas peran aktifnya dalam membantu pemerintah dalam mempercepat penanganan COVID-19.

"Anugerah ini juga merupakan apresiasi pemerintah kepada 125 donatur yang mendukung penanganan COVID-19 berupa pemberian bantuan yang disalurkan melalui BNPB. Diharapkan kolaborasi ini dapat terus berlanjut sebagai wujud kepedulian dunia usaha kepada masyarakat yang terdampak bencana alam maupun non alam".

\section{Alasan Pengungkapan PT. Adaro Energy, tbk selama Pandemi COVID-19}

Pandemi COVID - 19 menimbulkan gelombang kemanusiaan yang besar dari individu, pemerintah hingga perusahaan. Kegiatan sosial perusahaan dinilai sebagai wujud Tanggung Jawab Sosial (CSR) bagi Indonesia. Dimulai sejak bulan Maret 2020 saat COVID -19 baru menyebar di Indonesia, Adaro mengambil peran melalui penyaluran sejumlah donasi melalui program "Adaro berjuang untuk Indonesia". Berikut ini merupakan beberapa alasan mengapa Adaro mengungkapkan kegiatan sosial (CSR) mereka melalui website resmi perusahaan dan media sosial perusahaan.

\section{Legitimasi Perusahaan}

CSR tidak hanya sekedar aktivitas kedermawanan (charity) atau aktivitas saling mengasihi (stewardship) yang bersifat suka rela, tetapi CSR juga harus dipahami sebagai kewajiban asasi korporasi. Teori legitimasi menjelaskan perusahaan dan komunitas sekitarnya memiliki relasi sosial yang erat karena keduanya terikat dalam suatu 'sosial contract' (Lako, 2011). Ashforth dan Gibbs (1990) dalam Chariri (2009) mengusulkan dua pendekatan yang bisa digunakan oleh perusahaan untuk memperoleh legitimasi, yaitu manajemen substantif dan manajemen simbolik. Manajemen substantif mengandung arti bahwa perusahaan betul-betul menerapkan strategi khusus untuk memperoleh legitimasi. Sedangkan manajemen simbolik berarti bahwa perusahaan hanya pura-pura menerapkan strategi tertentu namun pada praktiknya tidak.

Pandemi COVID-19 yang tidak pernah dibayangkan sebelumnya menghasilkan dampak buruk bagi perekonomian bangsa Indonesia. Adaro mengambil peran sebagai perusahaan dengan menyalurkan donasi, hal tersebut dapat dikatakan bahwa Adaro Energy menerapkan manajemen substantif untuk memperoleh legitimasi.

\section{Sinergitas Antara Adaro dengan Berbagai Pihak}

Rudito dan Famiola (2013) menyatakan bahwa konsep tanggung jawab sosial perusahaan (CSR) melibatkan tanggung jawab kemitraan antar pemerintah, lembaga sumber daya masyarakat, juga masyarakat setempat (lokal).

"Presiden Direktur Adaro, Garibaldi Thohir menyatakan "Adaro berjuang untuk Indonesia dan siap menggunakan sumber daya yang kami miliki untuk bersinergi dengan pemerintah dalam penanganan virus corona (COVID-19) di Indonesia. Dalam kondisi seperti ini kita harus bersama-sama, bersinergi dengan semua pihak sehingga dapat mengatasi dan mempercepat penanggulangan COVID-19. Semoga kontribusi kami ini dapat memberikan manfaat nyata bagi masyarakat dan bangsa Indonesia."

Pernyataan yang dikeluarkan Garibaldi Thohir tersebut menunjukkan bahwa sinergitas ini merupakan tanggung jawab bersama secara sosial antar stakeholders. Wujud sinergitas Adaro dilaksanakan dengan menyalurkan bantuan selama Pandemi COVID - 19. Pertama, sinergi ini mereka lakukan melalui kemitraan Adaro dengan Badan Nasional 
Penanggulangan Bencana (BNPB) melalui donasi sejumlah Rp. 20 miliar. Kedua, Adaro bekerjasama dengan Universitas Indonesia dengan memberikan bantuan senilai Rp 2,5 miliar kepada Fakultas Teknik Universitas Indonesia (FTUI) untuk pembuatan dan pendistribusian 100 ventilator COVENT-20 ke rumah sakit-rumah sakit yang membutuhkan. Berikut adalah pernyataan pihak UI terkait donasi Adaro.

"Dekan FTUI, Dr. Ir. Hendri D.S. Budiono, M.Eng. "Kerja sama dengan Adaro ini merupakan perwujudan sinergi antara universitas dan industri dalam mewujudkan hilirisasi riset yang berguna bagi Indonesia,"

Lalu, dilanjutkan dengan pernyataan Adaro sebagai berikut

"Kerja sama Adaro dengan Universitas Indonesia ini merupakan langkah kongkrit pihak swasta dalam membantu pemerintah dalam mempercepat penanganan COVID-19 dengan menggunakan kekuatan dalam negeri.

Ketiga, Adaro menyerahkan 500.000 masker non medis kepada masyarakat di berbagai kabupaten di Kalimantan Selatan dan Kalimantan Tengah.

\section{Menghasilkan Citra baik bagi Perusahaan}

Gardner and Martinko (1988) dalam Chariri (2009) menjelaskan bahwa teks naratif merupakan bagian yang memainkan peranan penting bagi perusahaan dalam membentuk image perusahaan. Melalui teks naratif, perusahaan secara aktif berusaha membentuk image positif dan menghindari image negatif. Perusahaan menyadari pentingnya citra /image perusahaan. Perusahaan dengan citra yang baik dapat dilihat melalui kepedulian sosial perusahaan. Adaro memanfaatkan Pandemi COVID - 19 dengan berperan aktif membangun citra baik perusahaan melalui sejumlah donasi yang mereka keluarkan. Adaro menjadi perusahaan swasta pertama yang berdonasi di masa awal Pandemi Covid 19 melalui program "Adaro berjuang untuk Indonesia". Selanjutnya, mereka secara rutin mengungkapkan kegiatan sosial mereka selama pandemi covid - 19 melalui sejumlah postingan di Instagram. Salah satunya, postingan video di Instagram pada tanggal 28 Maret 2020 dengan narasi berita

“.... Adaro merupakan perusahaan swasta pertama yang bekerja sama dengan Badan Nasional Penanggulangan Bencana (BNPB) untuk menyalurkan bantuan sejumlah Rp. 20 miliar yang didonasikan untuk kesehatan...."

Adaro mengungkapkan bahwa mereka adalah pihak swasta pertama yang bekerja sama dengan BNPB. Adaro menyadari hal ini sebagai salah satu wujud tanggung jawab perusahaan (CSR) mereka yang akan menghasilkan citra baik bagi perusahaan. Langkah Adaro dengan ikut berpartisipasi aktif selama pandemic covid melalui program "Adaro berjuang untuk Indonesia" membuat mereka berhasil menerima penghargaan dari BNPB pada tanggal 15 Oktober 2020. Anugerah ini merupakan apresiasi pemerintah kepada 125 donatur yang mendukung penanganan COVID-19 berupa pemberian bantuan yang disalurkan melalui BNPB.

\section{KESIMPULAN}

Dari analisa semiotika dapat disimpulkan bahwa dari beberapa pernyataan yang diungkapkan melalui website resmi perusahaan dan media sosial perusahaan yang berupa teks naratif baik berbentuk kalimat maupun gambar menunjukkan wujud kegiatan sosial perusahaan (CSR). Adaro secara aktif bersinergi dengan berbagai pihak selama Pandemi COVID - 19 dengan menyalurkan sejumlah donasi. Hal ini dilakukan Adaro untuk membentuk citra baik perusahaan. Citra baik perusahaan dapat berujung pada pemerolehan legitimasi atau pengakuan Adaro dari para stakeholder. Legitimasi ini terwujud dalam penghargaan yang diberikan Badan Nasional Penanggulangan Bencana (BNPB) atas peran aktif Adaro Energy dalam membantu pemerintah dalam mempercepat penanganan COVID-19.

Adaro Energi adalah perusahaan go public yang mampu bersinergi dengan pemerintah dalam penanganan COVID-19. Bagi perusahaan lain, diharapkan mampu ikut 
bersinergi selama pandemi. Bagi penelitian selanjutnya, pandemi belum berakhir sehingga data tentang CSR Adaro Energy masih berkelanjutan. Ini menjadi peluang bagi peneliti dalam melakukan penelitian eksploratori terkait CSR di tengah pandemic.

\section{DAFTAR PUSTAKA}

Abbas, A., Ilham, M., Triani, N., Arizah, A., \& Rayyani, W.O. (2020). The Involvement of Firms in Helping Fight the Pandemic of COVID-19: Evidence from Indonesia. Inovbiz: Jurnal Inovasi Bisnis, 8(1), 72-76.

Caroll, A. B \& Shabana K.M. (2010). The Business Case for Corporate Social Responsibility: A Review of Consepts, Research and Practice. International Journal of Management Reviews.

Chariri, Anis \& Nugroho, Firman Aji. (2009). Retorika dalam Pelaporan Corporate Social Responsibility: Analisis Semiotik atas Sustainability Reporting PT. Aneka Tambang Tbk. Palembang: Simposium Nasional Akuntansi XII.

Davis, K. (1973). The Case for and Againts Business Assumption of Social Responsibilities. Academy of Management Journal. $16: 312$ - 322.

Donaldson, Thomas \& Dunfee, Thomas W. (1994). Toward a Unfied Conception of Business Ethics: Integrative Social Contracs Theory. Academy of Management Review, 19 (2), 252-284

Dusuki, Asyraf Wajdi. (2008). What Does Islam Say About Corporate Social Responsibility? International Association for Islamic Economics. Review of Islamic Economics, 12(1), 228.

Elkington, John. (1997). Cannibals with Forks. The Triple Bottom Line of 21st Century Business. Oxford: Capstone Publishing, Ltd.

Gardner, W. \& J. Martinko. (1988). Impression Management in Organizations. Journal of Management. 14 (2), 321-338.

Haryamoko. (2008). Prakata, dalam Hoed, B. H., Semiotik dan Dinamika Sosial Budaya. Jakarta: FIB UI Depok.
Hoed, B. H., (2008). Semiotik dan Dinamika Sosial Budaya. Jakarta: FIB UI Depok. http://www.adaro.com/ https://www.instagram.com/p/CCKmiL_nPg $\mathrm{R} /$ ?igshid=ryqa4c9vulvm

Kotler, Philip \& Nancy, Lee. 2005. Corporate Social Responsibility: Doing the Most Good For Your Company and Your Cause. New Jersey: John Wiley \& Sons. Inc

Lako, Andreas. 2011. Dekonstruksi CSR dan Reformasi Paradigma Bisnis dan Akuntansi. Jakarta: Penerbit Erlangga.

Lantos, Geoffrey P. (2002). The Ethicality of Altruistic Corporate Social Responsibility. Journal of Consumer Marketing. 19 (3), $205-230$.

Mardikanto, Totok. (2014). Corporate Social Responsibility (Tanggungjawab Sosial Perusahaan). Bandung: Penerbit Alvabeta.

Moleong, Lexy J. (2004). Metodologi Penelitian Kualitatif: Edisi Revisi. Bandung: PT. Remaja Rosdakarya Offset.

Priyanti, Efi. Kamayanti, Ari \& Atmadja, Soesilowati. S. (2010). Mengeksplorasi Kepedulian Lingkungan dan Sosial PT. AKR Corporindo, Tbk. melalui Laporan CSR (Studi Semiotika dan Indeks Pengungkapan). Jurnal Media Mahardika, 9 (2), 75-97.

Rudito, Bambang \& Famiola, Mella. (2013). Corporate Social Responsibility. Bandung: Penerbit Rekayasa Sains.

Sekaran, Uma \& Bougie, Roger. (2019). Metode Penelitian Bisnis. Buku 2: Edisi 6. Jakarta: Penerbit Salemba Empat.

Yusuf, Muhammad Yasir. (2017). Islamic Corporate Social Responsibility: Teori dan Praktik. Depok: Penerbit Kencana. 